\section{Clinital Plotes:}

MEDICAL, SURGICAL, OBSTETRICAL, AND THERAPEUTICAL.

\section{UROTROPIN IN THE PYURIA OF TABES DORSALIS.}

BY WALKeR Overend, M.A., M.D. OXON., B.Sc. LOND., LATE SENIOR PHYSICIAN TO THE TOTTENHAM HOSPITAL AND RADCLIFFE TRAVELLING FELLOW.

THE following case presents some points of interest. The patient, who was 36 years of age, exhibited the classical symptoms and signs of locomotor ataxia-occasional lightning pains, loss of knee-jerk, muscular incoördination, and vesical troubles. About April, 1899, he first noticed that the bed was wet of a morning, and soon afterwards the urine began to dribble during the day. It gradually commenced to run faster, until after a few months he never passed it at all in a natural manner but suffered from complete incontinence. He was compelled to wear an indiarubber urinal constantly. In the spring of 1900 he resigned his situation and went to live at the seaside. In March, 1901, he consulted me, but not for treatment of the bladder condition, inasmuch as he considered that to be hopeless and incurable. He had, as an out-patient, attended one of the special London hospitals for several years. I persuaded him to take a mixture containing ergot for a time but it proved useless. I then recommended eight grains of urotropin daily but he did not persevere with it. In September, 1901, he contracted influenza but recovered after a few days. The urine was ammoniacal and contained much pus. He was then passing nearly two pints into the urinal during the night and sleep was restless and disturbed. The ignominy of the wretched condition preyed upon his mind and he was morbid, depressed, and hypochondriacal. The vesical weakness in consequence became aggravated. I emphasised the necessity of resuming the urotropin and of taking it regularly for some months, and, irrigation being declined, assured him that the urotropin would greatly benefit him. In February, 1902, he stated that eight grains of urotropin had been taken daily for five months and that he felt much better. There had been no sign of hæmorrhage. The urinal was now practically dry at bedtime; he passed on his own initiative about two pints without pain during the day and the urinal in the early morning contained less than three-quarters of a pint. Moreover, he slept well and was looking out for some employment. One day in January he experienced-for the first time in two years-the desire to micturate. Since then he has learnt to ride a bicycle and he makes use of the machine in his new situation. The urine is free from pus and albumin and has an acid reaction which it retains even after standing for 24 hours. The urinal contains not more than half a pint of urine in the morning and only a few drops at bedtime. I suggested that he should continue the use of the urotropin until the dribbling ceased.

The regular administration of other vesical disinfectants such as salol might have led to equally good results and it seems reasonable to attribute a share of the improvement at least to the asepsis produced by the diurnal exhibition of the drug. The presence of a normal urine within the bladder with the absence of pyuria gave the sphincter an opportunity to recover its tone and the detrusor vesicæ its power. The restoration of physical tone and general mental equilibrium - a result of much exercise in the open air-no doubt assisted and favourably reacted upon the beneficial action of the urotropin. The addition of from one-fiftieth to one-hundredth of a grain of strychnine to the urotropin would probably facilitate the effect. The same combination may be suggested for the chronic vesical catarrh and pyuria of enlarged prostate and of diabetes as well as that of hemiplegia and senile debility.

Clacton-on-sea.

\section{CASES OF STOKES-ADATIS DISEASE (?).}

By IsaaC Crawford, L.R.C.P. \& S. Edin., L.F.P.S. Glasg.

EIGHT years ago I attended a woman during an attack of pneumonia. She was above medium height, married, of sallow complexion, and very thin. There was nothing about the pneumonia to call for special comment, save that resolution was somewhat delayed.

At the end of the first week of the illness, having been hurriedly summoned, as she was supposed to be dying, I found her pulseless at the wrists and quite unconscious while her breathing was imperceptible. There was a faint, slow flicker to be detected with difficulty in the region of the cardiac apex. Injections of strychnine and digitalin were employed and heat was applied to the extremities and præcordia. She slowly revived, the heart-beats gaining in strength and rhythm until the heart behaved in its customary manner. On inquiry her friends said that the oncoming of unconsciousness was gradual. She had five similar attacks, there being an interval of several days prior to the last which proved fatal. Digitalis was given and curiously enough it was stopped about a couple of days before the last attack. Whether that contributed to the fatal result it is hard to say. In the intervals the heart was normal, no murmur or irregularity being observable. There was no history of any previous similar attacks.

About the same time I attended another patient whose heart behaved in a manner somewhat similar to the above. She was a primipara whom 1 delivered with instruments under chloroform. There was some hæmorrhage but not enough to be dignified by the name of post-partum hæmor rhage. She then for no obvious cause passed gradually into a state of unconsciousness. Her pulse became slower and weaker and finally could not be felt at the wrists; her breathing could not be perceived; her cheeks became white; her limbs grew cold; and the fingers could not detect any sign of life at the cardiac apex. She lay in bed as motionless as if she were carved out of marble. Similar steps towards restoration were taken as in the previous case but I had to leave her still unconscious. Early in the morning I called again at the house and to my great relief I found her in excellent spirits and condition. She had recovered shortly after my departure.

There are references to the above condition in some of the text-books but nothing clear or explicit. I am unable to offer any explanation of the phenomena now described.

Tredegar, Mon.

\section{d attlitror}

\section{HOSPITAL PRACTICE, BRITISH AND FOREIGN.}

Nulla autem est alia pro certo noseendi via, nisi quamplurimas et morborum et dissectionum historias, tum aliorum tum propria collectas habere, ot inter se comparare.-MorgaGNI De Sed. et Caus. Morb., lib. iv., Procmium.

\section{ROMFORD UNION INFIRMARY.}

A FATAL CASE OF TETANY IN ASSOCIATION WITH DILATATION OF THE SMALL INTESTINE.

(Under the care of Dr. Dudley G. GReEnfield.)

A MARRIED woman, aged 33 years, was admitted into Romford Union Infirmary under the care of Dr. Greenfield on August 29th. She had had three children, the youngest of whom was nine months old. About 12 days before admission she had been seized with vomiting and had been steadily getting worse. She had previously had no serious illnesses but for some weeks she had been badly fed and cared for. The bowels had been relieved twice during this time on the administration of an enema. On admission the patient had a very worn appearance and complained of lack of sleep owing to the vomiting. She had no acute pain at any time. The vomiting was distressing and very frequent. The vomit was distinctly fæcal in odour and in appearance it was very like a characteristic typhoid stool. The abdomen was considerably distended and tympanitic on percussion, the normal areas of dulness being preserved. It moved fairly well on respiration, no pain was caused on palpation, and no tumour could be felt. The abdominal wall was not in the least rigid and no peristalsis was visible. The bowels had been relieved two days previously after an enema and the patient's gereral condition was fairly good. A soap enema was administered and a 